\title{
UJI AKTIVITAS PENYUBUR RAMBUT EMULGEL EKSTRAK ETANOL BUAH CABAI GENDOT (Capsicum annum Var.Abbreviata) PADA MENCIT PUTIH (Mus musculus) JANTAN
}

\section{HAIR GROWTH ACTIVITY TEST OF EMULGEL ETHANOL EXTRACT OF GENDOT CHILI FRUIT (Capsicum annum Var.Abbreviata) IN MALE WHITE (Mus musculus) MICE}

\author{
Lela Sulastri, Sri Asih, Renny Amelia \\ Sekolah Tinggi Farmasi Muhammadiyah Cirebon \\ Jl. Cideng Indah No. 3 Kertawinangun, Kedawung, Cirebon
}

Summited : 02 Februari 2020 Reviewed : 26 Maret 2020

Accepted : 29 Maret 2020

\begin{abstract}
ABSTRAK
Sediaan penyubur rambut digunakan untuk merangsang pertumbuhan rambut yang digunakan dengan dioleskan pada kulit kepala. Bahan alam yang diperkirakan yang dapat digunakan adalah salah satunya adalah cabai. Cabai mengandung senyawa saponin, terpenoid, kuinon, alkaloid capsaicin, dan flavonoid yang mempunyai peranan dalam memacu pertumbuhan rambut. Esktrak Etanol buah cabai gendot (Capsicum annum Var.Abbreviata) diformulasikan dalam bentuk sediaan emulgel. Pada penelitian ini digunakan emulgel ekstrak etanol buah cabai gendot yang dibagi menjadi 2 formula, formula 1 (konsentrasi 2,5\%) dan formula 2 (konsentrasi 5\%). Penelitian ini dilakukan untuk mengetahui apakah emulgel ekstrak etanol buah cabai gendot memiliki aktivitas sebagai penyubur rambut dan formula manakah yang memiliki aktivitas paling optimum. Uji aktivitas penyubur rambut meliputi laju pertumbuhan rambut dan bobot rambut. Perlakuan dilakukan pada 5 kelompok mencit yang masing-masing terdiri atas 5 ekor mencit, meliputi kontrol positif, kontrol basis, kontrol normal, formula 1 dan formula 2. Analisis data dilakukan dengan uji normalitas, uji homogenitas, dilanjutkan dengan uji ANAVA dan Uji Beda Nyata Terkecil (BNT) atau uji Kruskal Wallis dan Uji Man Whitney. Berdasarkan hasil penelitian menunjukan bahwa emulgel ekstrak etanol buah cabai gendot konsentrasi $5 \%$ mempunyai aktivitas sebagai penyubur rambut berdasarkan parameter laju pertumbuhan yaitu $0,023 \mathrm{~cm} /$ hari dalam 28 hari.
\end{abstract}

.Kata kunci : ekstrak cabai gendot, aktivitas penyubur rambut

\begin{abstract}
Hair growth preparations are used to stimulate hair growth that is used by rubbing it on the scalp. One of the estimated natural materials that can be used is chili. Chili contains saponins, terpenoids, quinones, capsaicin alkaloids and flavonoids which have a role in stimulating hair growth. Ethanol extract of Gendot chili (Capsicum annum Var.Abbreviata) is formulated in the form of emulgel. In this research, the extract of Gendot chilli ethanol extract was used which was divided into 2 formulas, formula 1 (concentration $2.5 \%$ ) and formula 2 (concentration 5\%). This research was conducted to determine whether the ethanol extract of gendot chili fruit has activity as a hair growth and which formula has the most optimum activity. Hair growth activity tests include hair growth rate and hair weight. The
\end{abstract}


treatment was carried out on 5 groups of mice, each consisting of 5 mice, including positive control, base control, normal control, formula 1 and formula 2. Data analysis was carried out by normality test, homogeneity test, followed by ANAVA test and Real Difference Test The smallest (LSD) or Kruskal Wallis test and the Man Whitney . Based on the resuts of the reseach showed that the emulgel ethanol extract gendot chili fruit concentration of 5\% has activity as a hair growth rate parameters of $0,023 \mathrm{~cm} /$ day in 28 days.

Keywords: Gendot chili extract, hair growth activity

\section{Penulis Korespondensi :}

Lela Sulastri

Sekolah Tinggi Farmasi Muhammadiyah Cirebon

Email : lelasulastri79@yaho.co.id / 085860337189

\section{PENDAHULUAN}

Rambut rontok (hair loss) dapat terjadi pada semua orang baik pria maupun wanita dengan penyebabnya yang beraneka ragam, merupakan suatu kelainan di mana jumlah rambut lebih sedikit atau terlepas lebih banyak dari normal, dengan atau tanpa penipisan yang tampak. Normalnya rambut kepala terlepas sebanyak 80-120 helai/hari. Jumlah folikel rambut kepala normalnya sekitar 100.000 , dan disebut sebagai kelainan jika jumlahnya mencapai 50\% yang berarti sekitar 50.000 helai (Umborowati M.A dan , Rahmadewi 2012).Faktor yang dapat mempengaruhi terjadinya kerontokan rambut diantaranya adalah kurangnya nutrisi bagi pertumbuhan rambut seperti air, protein, vitamin A, vitamin $C$, vitamin B, Vitamin E dan zat besi (Musdalipah \& Karmilah, 2018). Penyebabnya kerontokan rambut dapat digolongkan menjadi endogen yaitu akibat penyakit sistemik, hormonal, status gizi, intoksikasi, maupun kelainan genetik; dan eksogen yaitu berupa stimulus dari lingkungan, maupun kosmetik rambut (Umborowati M.A dan, Rahmadewi 2012).

Solusi kerontokan rambut salah satunya yang sudah umum digunakan adalah dengan penggunaan berbagai produk penyubur rambut yang berasal dari zat sintesis seperti minoxidil. Namun, penggunaan minoxidil memungkinkan timbulnya efek samping seperti alergi kulit, sakit kepala, vertigo, edema sampai hipotensi (Messenger \& Rundegren, 2004). Dewasa ini peranan obat tradisional dalam usaha pencegahan dan pengobatan berbagai penyakit sudah berkembang pesat yang dapat ditemukan dalam berbagai bentuk sediaan. Hal ini didukung oleh berbagai bukti-bukti ilmiah maupun penelitian, baik secara kualitatif maupun kuantitatif untuk keamanan dan penggunaannya. Oleh karena itu, obat tradisional merupakan bidang yang masih diminati untuk diteliti ( Musdalipah \& Karmilah, 2018). Demikian halnya dengan produk penyubur rambut dewasa ini sudah banyak yang menggunakan bahan alam sebagai bahan aktinya.

Berdasarkan hasil studi etnofarmasi tanaman obat untuk penumbuh dan perwawatan rambut pada beberapa daerah di Indonesia yang dilakukan oleh Oktoba. Z (2018) telah diidentifikasi adanya 23 jenis tumbuhan obat yang berasal dari 20 family yang dapat digunakan sebagai penumbuh dan perawatan rambut, salah satunya adalah cabai. Secara empiris penggunaan cabe sebagai penyubur rambut sudah dilakukan oleh suku rejang yang memanfaatkan daun cabe rawit sebagai penumbuh rambut yaitu dengan menggunakan daun muda yang ditempelkan langsung pada bagian kepala (Oktoba. Z 2018). Pada penelitian yang dilakukan oleh Musdalipah \& Karmilah (2018) bahwa ekstrak daun cabai rawit konsentrasi 5\%,10\% dan 20\% dapat memberikan efek dalam proses pertumbuhan rambut dengan pertumbuhan rambut optimum ditunjukan oleh esktrak konsentrasi $20 \%$. Berdasarkan penelitian Yunita (2012) bahwa daun cabe rawit memiliki aktivitas antioksidan dengan nilai IC $5048,28 \mathrm{ug} / \mathrm{ml}$, adanya antioksidan dalam cabe memounyai peranan penting dalam pertumbuhan rambut karena antioksidan dapat melawan radikal bebas sehingga pertumbuhan rambut dapat terjadi secara maksimal. Antioksidan memiliki peranan penting dalam mencegah atau menunda timbulny penyakit degeneratif melalui mekanisme 
penghambatan proses oksidasi yang menyebabkan penyakit kronik dan menunda waktu terjadinya aging. Dimana terdapat dua golongan antioksidan endogen (senhawa yang dihasilkan oleh tubuh yang memiliki sifat oksidatif) dan eksogen (seperti vitamin E, vitamin $\mathrm{C}$ dan falvonoid). Cabe rawit sendiri mengandung saponin, alkaloid, terfenoid, kuinon dan falvonoid (Musdalipah \& Karmilah 2018 )

Daun cabai rawit mengandung zat aktif berkhasiat diantaranya alkaloid capsisin, terfenoid, saponin dan capsaisin (Soumnya, S.L dan Bindu R Nair 2012) . Saponin merupakan senyawa yang mampu menstimulasi pertumbuhan rambut, dimana saponin dapat meningkatkan sirkulasi darah perifer ke folikel rambut sehingga mampu meningkatkan pertumbuhan rambut (Suparjo 2009). Capsaicin dalam cabai membantu merangsang pertumbuhan rambut, karena rasa panas dari capsaicin tersebut dapat membuka pembuluh darah sehingga dapat meningkatkan sirkulasi darah di bagian kulit kepala. Flavonoid berperan sebagai antioksidan sehingga mampu memacu pertumbuhan rambut (Musdalipah \& Kamilah, 2018)

Cabai memiliki banyak varietas diantaranya adalah cabe gendot (Capsicum annum Var.Abbreviata) merupakan tanaman yang mengandung senyawa kimia diantaranya saponin, alkoloid, terpenoid, kuinon, dan flavonoid. Selain cabai mengandung senyawa kimia saponin, alkaloid, terpenoid, kuinon, dan flavonoid. Cabai juga mengandung senyawa capsaicin yang dapat merangsang folikel rambut dan membantu rambut tumbuh (Musdalipah \& Karmilah (2018)

Berdasarkan hal tersebut maka pada penelitian ini digunakan ekstrak cabe gendot yang diperoleh dengan metode maserasi dengan cairan pelarut etanol $70 \%$ yang diformulasikan dalam bentuk sediaan emulgel penyubur rambut. Jumlah ekstrak etanol cabe gendot yang digunakan 2,5 \% dan $5 \%$ mengacu kepada penelitian Musdalipah \& Karmilah (2018) yang menggunakan daun cabe rawit dimana konsentrasi $20 \%$ memberikan efek optimum dan dipilih konsentrasi tersebut karena bagian cabe gendot yang digunakan adalah buahnya dimana tingkat kepedasannya lebih pedas daripada daun. Digunakan sediaan emulgel karena emulgel memiliki stabilitas yang baik yang merupakan kombinasi antara emulsi tipe minyak dalam air (o/w) atau air dalam minyak (w/o) dengan basis gel (Anwar dkk, 2013). Emulgel mempunyai kelebihan antara lain untuk menghindari metabolisme lintas pertama, dapat diaplikasikan sendiri oleh pemakai, dapat meningkatkan penerimaan pasien, dan dapat dgunakan untuk obat yang mempunyai waktu paruh rendah (Anwar dkk 2013). Terhadap sediaan emulgel tersebut dilakukan uji aktivitas penyubur rambut dengan tujuan untuk mengetahui apakah kedua sediaan emulgel tersebut memiliki aktivitas sebagai penyubur rambut dan formula manakah yang memiliki aktivitas penyubur rambut yang paling optimal. Uji aktivitas penyubur rambut dilakukan berdasarkan parameter laju pertumbuhan rambut dan bobot rambut.

\section{METODE PENELITIAN}

\section{Alat dan Bahan}

Alat yang digunakan adalah neraca analitik (Ohaus), pencukur rambut (veet), kertas perkamen, beaker glass (pyrex), pinset, jangka sorong (tricle brand), solatip putih, solatip hitam, plastik klip, gunting, pot salep. Bahan yang digunakan adalah emulgel ekstrak etanol buah cabai gendot (Capsicum annum Var.Abbreviata) Formula 1 (2,5\%) dan Formula 2 (5\%), Basis Emulgel, Hair Tonic Merk X dan etanol 70\%.

\section{Hewan Uji}

Hewan uji yang digunakan adalah mencit putih jantan dengan bobot badan \pm 20 gram. Pada penelitian ini jumlah hewan uji coba yang digunakan adalah 25 ekor mencit putih jantan yang dibagi menjadi 5 kelompok, masing-masing kelompok terdiri dari 5 mencit. 


\section{Jalannya Penelitian}

\section{Penyiapan Hewan Uji}

Hewan uji yang digunakan adalah mencit putih (Mus musculus) yang sehat diadaptasikan selama seminggu setelah pembelian. Setelah itu mencit dibagi dalam 5 kelompok yaitu formula 1 (konsentrasi 2,5\%), formula 2 (konsentrasi 5\%), kontrol positif (hair tonic merk $\mathrm{X})$, kontrol basis (basis emulgel), kontrol normal (tanpa perlakuan) dan semua mencit yang akan digunakan dalam penelitian ini adalah mencit jantan. Hair tonic merk $\mathrm{X}$ dijadikan sebagai kontrol positif karena mengandung sejumlah vitamin ekstrak Aloe Vera yang sudah terbukti sebagai penyubur rambu

\section{Penyiapan hewan uji setelah adaptasi}

Hewan uji sebelum digunakan diadaptasikan selama 1 minggu ( 7 hari) dengan ditempatkan dalam kandang plastik dengan tutup terbuat dari kawat ram dan dialasi sekam, pakan berupa pelet dan air minum diberikan ad libitum. Lingkungan kandang dibuat agar tidak lembab, ventilasi yang cukup serta penyinaran yang cukup, dimana lamanya terang 14 jam dan lama gelap 10 jam. Sebelum melakukan percobaan tikus diadaptasi dalam kandang selama 7 hari untuk menyeragamkan cara hidup dan makanannya,. Kesehatan tikus dipantau setiap hari, dan berat ditimbang setiap minggu. Setelah mencit beradaptasi maka selanjutnya punggung mencit dibersihkan dari rambut dengan cara dicukur hingga bersih, untuk daerah pengolesan masing-masing berbentuk segi empat dengan ukuran $2 \times 2 \mathrm{~cm}$. Sebelum dilakukan pengolesan, punggung mencit yang telah dicukur diolesi etanol $70 \%$ sebagai antiseptik.

\section{Uji aktivitas penyubur rambut emulgel ekstrak etanol buah cabai gendot (Capsicum annum Var.Abbreviata)}

Untuk menguji aktivitas emulgel ekstrak etanol buah cabai gendot terhadap laju pertumbuhan rambut dilakukan dengan mengoleskan sediaan sebanyak 1 gram dilakukan setiap hari 2 kali yaitu pagi dan sore pada masing-masing mencit. Hari pertama pengolesan dianggap hari ke-0. Pengamatan dilakukan selama 28 hari, dengan mengambil 6 helai rambut mencit tiap 7 hari sekali, dihitung pada hari ke-7, ke-14, ke-21, dan ke-28. Rambut diambil dengan cara dipotong, diluruskan diatas solatip hitam dan ditempelkan pada solatip putih, kemudian diukur panjang rambut dengan menggunakan jangka sorong. Pada hari ke-28 dilakukan pencukuran rambut, semua rambut pada area perlakuan dipotong dan ditimbang beratnya (Indriaty S dan Sulastri L 2016).

Tabel I. Formula emulgel ekstrak etanol buah cabai gendot

\begin{tabular}{|c|c|c|c|}
\hline \multirow{2}{*}{ Bahan } & \multicolumn{3}{|c|}{ Konsentrasi (\%) emulgel } \\
\hline & Formula 1 & Formula 2 & Basis Emulgel \\
\hline $\begin{array}{l}\text { Ekstrak etanol } \\
\text { buah cabai gendot }\end{array}$ & 2,5 & 5 & - \\
\hline karbomer & 2 & 2 & 2 \\
\hline $\mathrm{NaOH} 0,1 \mathrm{~N}$ & 0,6 & 0,6 & 0,6 \\
\hline Minyak Zaitun & 5 & 5 & 5 \\
\hline Tween 60 & 3,6 & 3,6 & 3,6 \\
\hline Span 20 & 1,4 & 1,4 & 1,4 \\
\hline Propilenglikol & 10 & 10 & 10 \\
\hline Etanol 96\% & 3 & 3 & 3 \\
\hline Menthol & 1 & 1 & 1 \\
\hline BHT & 0,03 & 0,03 & 0,03 \\
\hline Aquadestillata & ad 100 & ad 100 & ad 100 \\
\hline
\end{tabular}




\section{Analisis Data}

Uji aktivitas penyubur rambut meliputi laju pertumbuhan rambut dan bobot rambut. Laju pertumbuhan rambut diperoleh dari panjang rambut. Data panjang rambut dan bobot rambut yang diperoleh selanjutnya diolah secara statistik untuk melihat apakah ada perbedaan yang bermakna antara daerah uji dengan kontrol. Untuk melihat normalitas serta homogenitas data, dilakukan uji Normalitas (Saphiro-Wilk) dan uji homogenitas (Levene). Distribusi data yang normal dan homogen diolah untuk uji Anova. Tujuan dilakukan Anova adalah untuk mengetahui ada atau tidaknya perbedaan yang bermakna secara statistik dari kelompok perlakuan secara keseluruhan. Selanjutnya, untuk melihat perbedaan bermakna secara statistik antar kelompok uji, maka dilakukan uji beda nyata terkecil (BNT). Distribusi data yang tidak normal atau tidak homogen diolah menggunakan statistik nonparametik yaitu uji Kruskal Wallis. Kemudian dilanjutkan dengan uji Mann-Whitney untuk melihat adanya perbedaan bermakna pada masing-masing kelompok uji dengan tingkat kepercayaan sebesar 95\% (Amin. dkk., 2014).

\section{HASIL DAN PEMBAHASAN}

a. Rata-rata panjang rambut mencit yang diberi emulgel ekstrak etanol buah cabai gendot

Tabel II. Rata-rata panjang rambut hari ke-7 sampai dengan hari ke-28

\begin{tabular}{lcccc}
\hline & \multicolumn{4}{c}{ Rata-Rata Panjang Rambut $(\mathrm{cm}) \pm \mathrm{SD}$} \\
\cline { 2 - 5 } Perlakuan & 7 & 14 & 21 & 28 \\
\hline Konsentrasi 2,5\% & $0^{\mathrm{c}}$ & $0,378 \pm 0,073^{\text {cd }}$ & $0,516 \pm 0,03^{\text {cd }}$ & $0,609 \pm 0,015^{\text {cd }}$ \\
\hline Konsentrasi 5\% & $0^{\mathrm{c}}$ & $0,482 \pm 0,052^{\mathrm{d}}$ & $0,595 \pm 0,04^{\mathrm{d}}$ & $0,666 \pm 0,027^{\mathrm{d}}$ \\
\hline Kontrol Positif & $0,335 \pm 0,03$ & $0,558 \pm 0,05^{\mathrm{d}}$ & $0,651 \pm 0,064^{\mathrm{d}}$ & $0,741 \pm 0,059^{\mathrm{d}}$ \\
\hline Kontrol basis & $0^{\mathrm{c}}$ & $0,461 \pm 0,021^{\mathrm{c}}$ & $0,539 \pm 0,018^{\mathrm{cd}}$ & $0,647 \pm 0,023$ \\
\hline Kontrol Normal & $0^{\mathrm{c}}$ & $0,299 \pm 0,025^{\mathrm{c}}$ & $0,432 \pm 0,046^{\mathrm{c}}$ & $0,547 \pm 0,041^{\mathrm{c}}$
\end{tabular}

Keterangan :

$\mathrm{C}=$ berbeda bermakna dengan kontrol positif

$\mathrm{D}=$ berbeda bermakna dengan kontrol normal

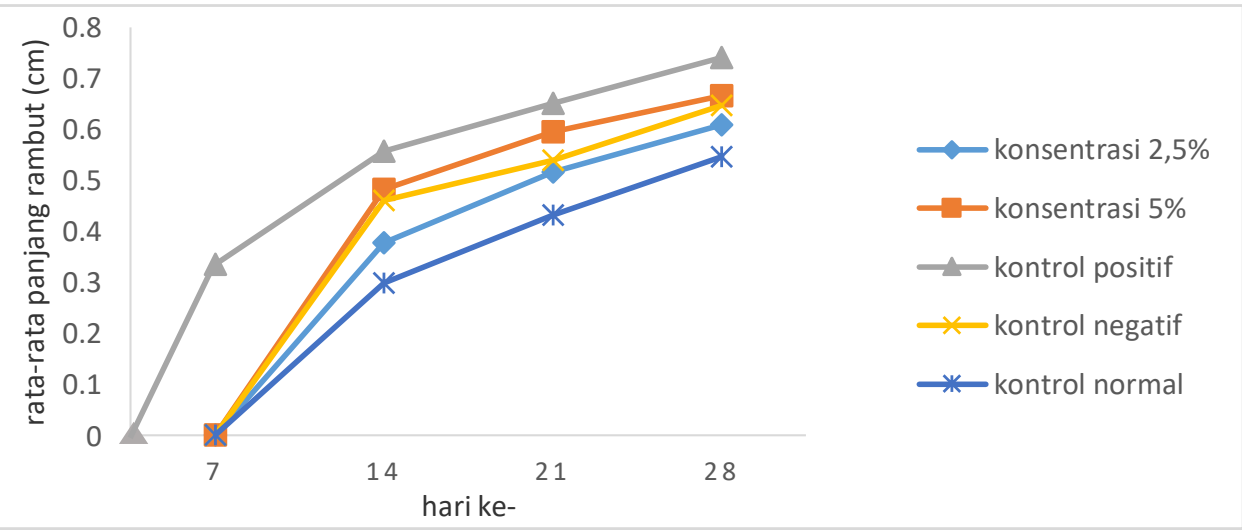

Gambar 1. Rata-rata panjang rambut mencit hari ke-7 sampai dengan hari ke-28

Uji aktivitas pertumbuhan rambut dilakukan pada hari ke-7, 14, 21, dan 28 dengan parameter yang diamati yaitu panjang rambut setiap 7 hari sekali dan bobot rambut pada hari ke-28. Data rata-rata panjang rambut mencit pada tabel 4.6 dan gambar 4.1 menunjukan bahwa adanya pertumbuhan panjang rambut setiap minggunya pada masing-masing perlakuan. Pertumbuhan rambut untuk kontrol positif dimulai pada hari ke-7, sedangkan untuk kelompok perlakuan formula 1 (konsentrasi 2,5\%), formula 2 (konsentrasi 5\%), 
kontrol basis, dan kontrol normal dimulai pada hari ke-14. Dimana pada hari ke-28 rambut terpanjang dimiliki oleh kontrol positif yaitu $0,741 \mathrm{~cm}$ dan rambut terpendek dimiliki oleh kontrol normal yaitu $0,547 \mathrm{~cm}$. Adapun untuk emulgel penyubur rambut formula $2(0,666$ $\mathrm{cm})$ memiliki panjang rambut yang lebih panjang dari formula $1(0,605 \mathrm{~cm})$ karena formula 2 mengandung jumlah ekstrak yang lebih besar dibandingkan dengan formula 1. Kontrol normal menunjukan pertumbuhan rambut normal karena tidak menerima perlakuan apapun. Kontrol basis merupakan kontrol untuk melihat apakah basis emulgel memiliki aktivitas sebagai penyubur rambut atau tidak. Sedangkan untuk kontrol positif sebagai pembanding dan validasi metode.

Dari pengolahan data secara statistik pada hari ke-28 menunjukan terdapat perbedaan yang bermakna/signifikan $\leq \alpha(0,05)$ antara kontrol normal dengan konsentrasi $2,5 \%$ dan konsentrasi $5 \%$. Konsentrasi $5 \%$ tidak menunjukan adanya perbedaan bermakna terhadap kontrol positif, sedangkan konsentrasi $2,5 \%$ menunjukan adanya perbedaan bermakna terhadap kontrol positif. Dengan demikian pada hari ke-28 hanya formula $2(5 \%)$ memiliki aktivitas sebagai penyubur rambut.

b. Laju pertumbuhan

Tabel III. Laju pertumbuhan rambut mencit

\begin{tabular}{lcccc}
\hline & \multicolumn{4}{c}{ Rata-rata panjang rambut (cm/hari) } \\
\cline { 2 - 5 } Perlakuan & 7 & 14 & 21 & 28 \\
\hline $\begin{array}{l}\text { Konsentrasi } \\
2,5 \%\end{array}$ & 0,000 & 0,027 & 0,024 & 0,022 \\
\hline Konsentrasi 5\% & 0,000 & 0,034 & 0,028 & 0,023 \\
\hline Kontrol Positif & 0,047 & 0,036 & 0,029 & 0,025 \\
\hline Kontrol Basis & 0,000 & 0,033 & 0,025 & 0,023 \\
\hline Kontrol Normal & 0,000 & 0,021 & 0,020 & 0,019 \\
\hline
\end{tabular}

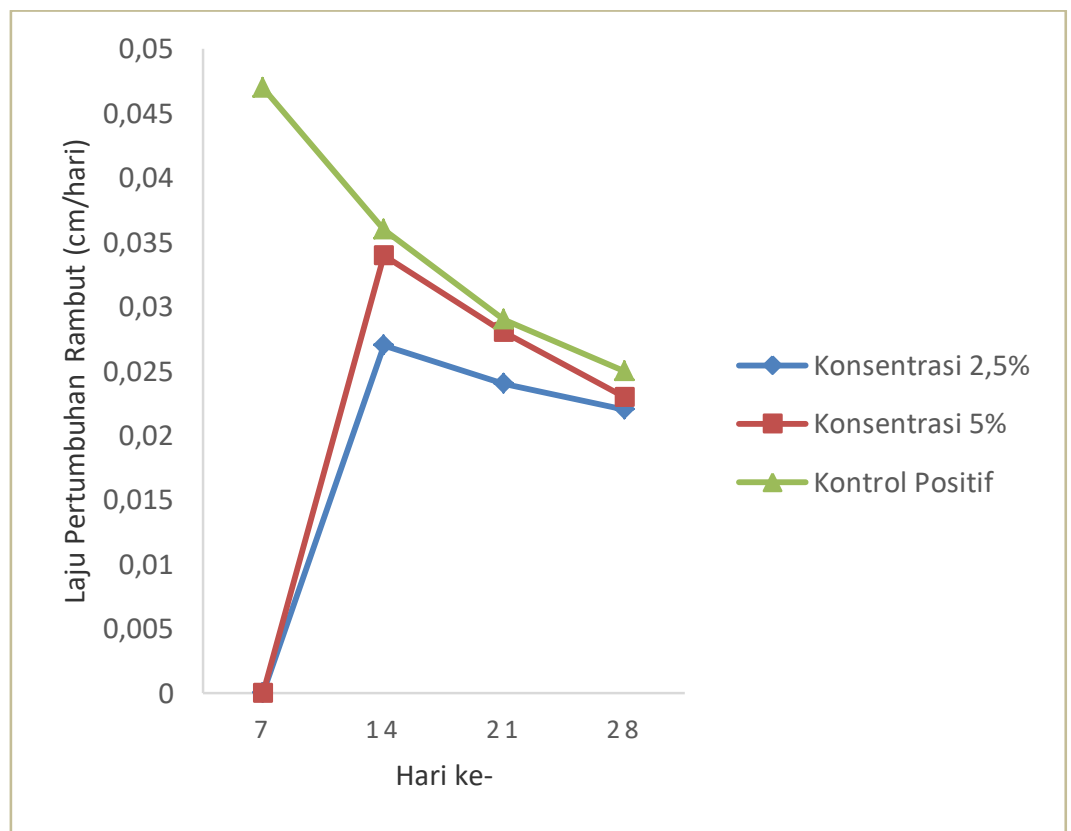

Gambar 2 Grafik laju pertumbuhan rambut mencit (kelompok perlakuan dibandingkan dengan kontrol positif) 


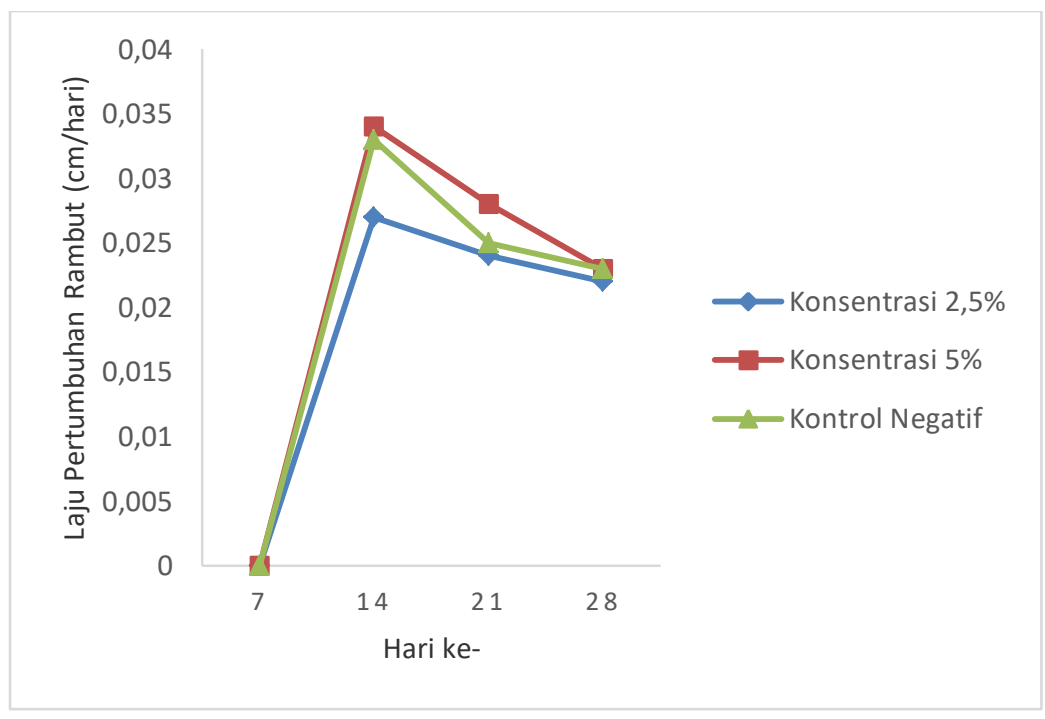

Gambar 3 Grafik laju pertumbuhan rambut mencit (kelompok perlakuan dibandingkan dengan kontrol basis/negatif)

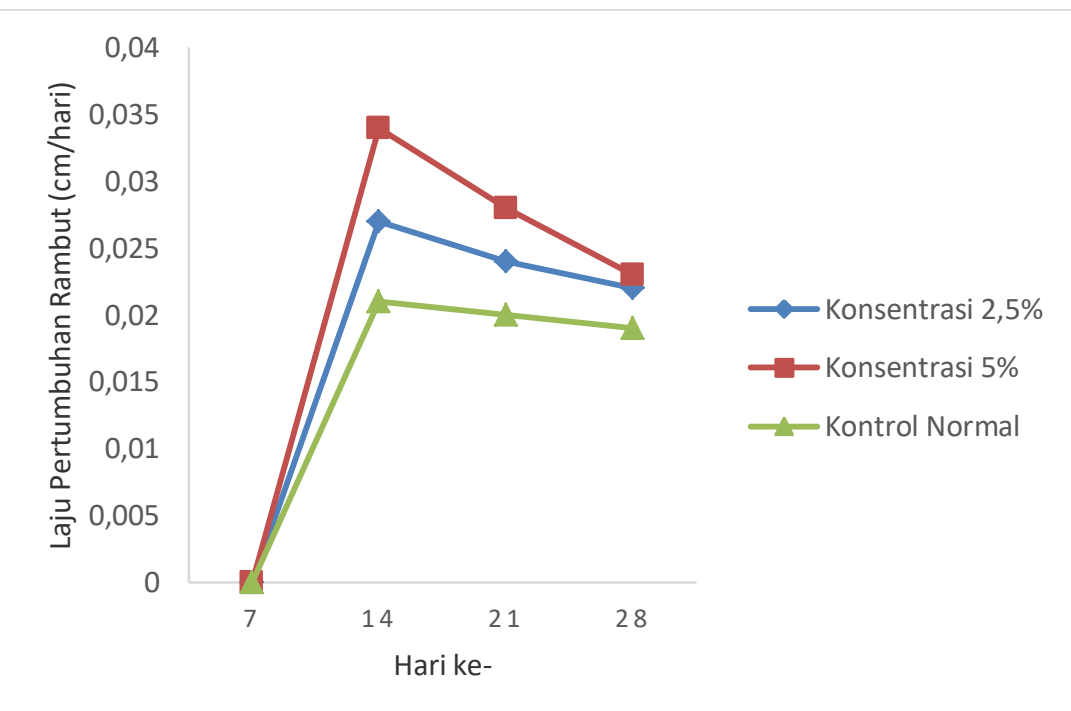

\section{Gambar 4 Grafik laju pertumbuhan rambut mencit (kelompok perlakuan dibandingkan dengan kontrol normal)}

Berdasarkan rata-rata panjang rambut diperoleh data laju pertumbuhan rambut, dimana kelompok perlakuan dibandingkan dengan kontrol positif menunjukan bahwa kontrol positif $(0,047 \mathrm{~cm} /$ hari) mempunyai laju pertumbuhan rambut lebih cepat dibandingkan dengan emulgel konsentrasi 2,5\% (0,027 cm/hari) dan konsentrasi 5\% (0,034 cm/hari). Pada grafik laju pertumbuhan rambut baik konsentrasi $2,5 \%$, konsentrasi $5 \%$ dan kontrol positif mengalami penurunan secara perlahan tiap minggunya.

Laju pertumbuhan rambut dari kelompok perlakuan dibandingkan dengan kontrol basis menunjukan bahwa laju pertumbuhan tercepat terjadi pada hari yang sama yaitu hari ke-7, konsentrasi $5 \%(0,034 \mathrm{~cm} / \mathrm{hari})$ mempunyai kecepatan yang lebih cepat dari pada konsentrasi 2,5\% (0,027 cm/hari) dan kontrol basis $(0,033 \mathrm{~cm} /$ hari). Pada hari ke-14 baik kelompok perlakuan maupun kontrol basis mengalami penuruan tiap minggunya secara perlahan. Kontrol basis memiliki laju pertumbuhan lebih cepat dibandingkan konsentrasi $2,5 \%$. 
Laju pertumbuhan rambut dari kontrol normal lebih rendah dibandingkan dengan kelompok perlakuan. Laju pertumbuhan rambut yang paling cepat pada kontrol normal maupun kelompok perlakuan terjadi pada hari yang sama yaitu hari ke-7. Dimana laju pertumbuhan rambut yang dimiliki emulgel dengan konsentrasi $5 \%(0,034 \mathrm{~cm} /$ hari) lebih cepat dari pada emulgel dengan konsentrasi $2,5 \%(0,027 \mathrm{~cm} / \mathrm{hari})$ dan kontrol normal $(0,021)$. Pada hari ke14 semuanya mengalami penurunan laju secara perlahan sampai dengan hari ke-28. Dengan demikian maka emulgel dengan konsentrasi 5\% dibandingkan dengan konsentrasi 2,5\% dan kontrol normal mempunyai laju pertumbuhan rambut tercepat. Laju pertumbuhan rambut kontrol normal menunjukan bahwa pertumbuhan rambut tumbuh secara alami atau tanpa perlakuan.

c. Bobot rambut

Tabel IV. Bobot rambut mencit

\begin{tabular}{lccccccc}
\hline & \multicolumn{6}{c}{ Hari } & \multicolumn{6}{c}{ Bobot rambut $(\mathrm{g})$} & Rata-rata & SD \\
\cline { 2 - 7 } Perlakuan & 1 & 2 & 3 & 4 & 5 & & \\
\hline Konsentrasi 2,5\% & 0,0184 & 0 & 0,0304 & 0,0243 & 0,0215 & $0,0236^{\mathrm{c}}$ & 0,0051 \\
\hline Konsentrasi 5\% & 0,0212 & 0,0246 & 0,038 & 0,0259 & 0,0239 & $0,0267^{\text {cd }}$ & 0,0058 \\
\hline Kontrol Positif & 0,0346 & 0,0354 & 0,0429 & 0,0387 & 0,0392 & $0,0381^{\mathrm{d}}$ & 0,0029 \\
\hline Kontrol Basis & 0,0295 & 0 & 0,0213 & 0,0228 & 0,0234 & $0,0242^{\text {cd }}$ & 0,0036 \\
\hline Kontrol Normal & 0,021 & 0,0205 & 0,0198 & 0,0208 & 0,0217 & $0,0207^{\mathrm{c}}$ & 0,0006 \\
\hline
\end{tabular}

Keterangan :

$\mathrm{C}=$ berbeda bermakna dengan kontrol positif

$\mathrm{D}=$ berbeda bermakna dengan kontrol normal



Gambar 5. Diagram batang bobot rambut mencit

Pada hari ke-28 dilakukan penimbangan bobot rambut. Hal ini dilakukan untuk mengetahui ketebalan dan diameter rambut yang dihasilkan oleh penyubur rambut tersebut. Dimana kontrol positif mempunyai bobot rambut yang lebih besar yaitu 0,0381 gram dan bobot rambut terendah dimiliki oleh kontrol normal yaitu 0,0207 gram, karena kontrol normal menunjukan pertumbuhan rambut yang tumbuh secara alami tanpa perlakuan . Formula 2 (0,0267 gram) memiliki bobot rambut terbesar dibandingkan dengan formula 1 $(0,0236$ gram $)$ karena jumlah ekstraknya lebih besar. 
Berdasarkan pengolahan data analisa statistik pada hari ke-28 dengan uji Kruskal Wallis menunjukan bahwa terdapat perbedaan yang signifikan/bermakna dari rata-rata bobot rambut mencit karena nilai signifikan $\leq \alpha(0,05)$. Berdasarkan uji Mann Whitney menunjukan tidak adanya perbedaan antara konsentrasi 2,5\% terhadap kontrol normal, dan adanya perbedaan konsentrasi 5\% dengan kontrol normal. Dibandingkan dengan kontrol basis kedua formula menunjukan tidak adanya perbedaan yang bermakna, dan dengan kontrol positif menunjukkan adanya perbedaan bermakna. Hal ini menunjukan bahwa kedua formula tidak memiliki beraktivitas untuk menebalkan rambut.

Dengan demikian maka emulgel ekstrak etanol cabe gendot $2,5 \%$ tidak memiliki aktivitas sebagai penyubur rambut baik berdasarkan parameter laju pertumbuhan rambut maupun bobot rambut, sedangkan emulgel ekstrak etanol cabe gendot $5 \%$ memiliki aktivitas penyubur rambut berdasarkan parameter laju pertumbuhan rambut.

\section{KESIMPULAN}

Emulgel ekstrak etanol buah cabai gendot konsentrasi $5 \%$ mempunyai aktivitas sebagai penyubur rambut berdasarkan parameter laju pertumbuhan yaitu $0,023 \mathrm{~cm} / \mathrm{hari}$.

\section{DAFTAR PUSTAKA}

Amin, J. Simamora, E.L.P. Anwar, E. Djajadisastra, J. 2014. Green Tea (Camellia sinensis L) Ethanolic Extract As Hair Tonic In Nutraceutical; Physical Stability, Hair Growth Activity On Rats And Safety Test. International Journal Of Pharmacy And Pharmaceutical Sicences. 6(1): 94-95.

Anwar, E. Ramadon, D. Hemita. 2013. Formulation An Evaluation Of Gel And Emulgel Of Chili Extract (Capsicum frutescens L) As Topical Dosage Forms. Academic Sicences. 6(1): 13-16.

Indriaty S , Sulastri S, 2016 Uji Aktivitas Ekstrak Air Akar Manis (Glycyrrhiza Glabra L.) Sebagai Penyubur Rambut Pada Kelinci Jantan Hair Growth Activity Test Of Water Extract Liquarice Medical Sains Vol 1 No 1 26-27.

Messenger, A.G. \& Rundegren, J. 2004. Minoxidil: Mechanisms Of Action On Hair Growth. British Journal Of Dermatology. 150: 186-194.

Musdalipah \& Karmilah. 2018. Efektivitas Ekstrak Daun Cabai Rawit (Capsicum frutescents L.) Sebagai Penumbuh Rambut Terhadap Hewan Uji Kelinci (Oryctolagus cuniculus). Riset Informasi Kesehatan. 7(1): 83-88.

Oktoba , Z. 2018 Studi Etnofarmasi Tanaman Obat Untuk Perawatan dan Penumbuh Rambut Pada Beberapa Daerah Di Indonesia, Jurnal Jamu Indonesia, 3(3) 81-88.

Sari, D.K. \& Wibowo, A. 2016. Perawatan Herbal Pada Rambut Rontok. Majority. 5(5): 129-134.

Suparjo. 2009. Saponin : Peran dan Pengaruhnya Bagi Ternak dan Manusia, Jambi: Universitas Jambi.

Sona, F.R. 2018. Formulasi Hair Tonis Ekstrak Lidah Buaya (Aloe vera (L) Burm.F) dan Uji Aktivitas Pertumbuhan Rambut Pada Tikus Putih Jantan. Skripsi. Malang: Universitas Maulana Malik Ibrahim Malang. 32-33.

Soumnya, S.L dan Bindu L. Nair. 2012. Antifungal Efficacy Of Capsicum frutescens L. Extracts Egaints Some Prevalent Fungal Strains Assosiated With Groundnut Storage. Journal Of Agricultural Technologi, Vol 8(2) : 739-750

Umborowati M.A, Rahmadewi 2012 Rambut Rontok Akibat Lingkungan dan Kosmetik (Environment and Cosmetic Induced Hair Loss) Berkala Ilmu Kesehatan Kulit \& Kelamin Vol 4 No 1Departemen/Staf Medik Fungsional Ilmu Kesehatan Kulit 35

Yunita 2012 Uji Aktivitas Antioksidan Ekstrak dan Fraksi Ekstrak Daun Cabe Rawit (Capsicum frutescens L) dan Identifikasi Golongan Senyawa dari Fraksi Teraktif. Skripsi tidak dipubilkasikan. Fakultas Matematika dan Ilmu Pengetahuan Alam, Program Studi Farmasi, Depok, Universitas Indonesia. 
